\title{
Asian American Women's Resilience: An Integrative Review
}

Asian/Pacific Island Nursing Journal

Volume 1(3): 105-115

(C)Author(s) 2016

http://digitalscholarship.unlv.edu/apin/

\author{
Andrew Thomas $\operatorname{Reyes}^{\mathrm{a}}$ and Rose E. Constantino ${ }^{\mathrm{b}}$
}

\begin{abstract}
Asian American women face unique stressors that threaten their overall health and well-being. However, resilience is a phenomenon that allows individuals to develop positive adaptation despite adversities and challenges. This integrative review is conducted in order to explore the current state of knowledge regarding the resilience of Asian American women. Twelve databases were used to identify related articles: Academic Search Premier, CINAHL, ERIC, Ethnic NewsWatch, GenderWatch, ProQuest Dissertations and Theses Global, ProQuest Sociological Abstracts, PsycINFO, PubMed, SAGE (Psychology and Sociology collections), Scopus, and Web of Science. Twenty-one research studies met the inclusion criteria of the integrative review. Five common themes emerged from the analysis of the studies: (a) resilience as conceptualized as a coping strategy, (b) resilience as related to social support and network, (c) resilience as an enduring phenomenon, (d) resilience as connected to bicultural identity, and (e) resilience as an emancipatory perspective and experience. These themes imply that resilience is a developmental process, culture has a significant influence on resilience, and Asian American women are a vulnerable and marginalized group. Further recommendations for nursing practice and research are discussed as related to these implications.
\end{abstract}

Keywords: Asian American women, coping, resilience, resiliency

Resilience is the ability to process and manage experiences that buffer the negative effects of stress; it allows individuals to overcome challenges and helps them develop positive adaptation skills despite setbacks (Dyer \& McGuinness, 1996; Luthar, Cicchetti, \& Becker, 2000; Rutter, 1993). The study of resilience among Asian American/Pacific Islander women is important because the context of their health is constantly changing, and the risk factors that influence their adversities are complex. Asian American/Pacific Islander women (referred to as AAPIW in this article) are those of Asian and Pacific Islander descent who live in the United States. The U.S. Census Bureau (2013) defines individuals of Asian descent as having origins in any of the following regions: Far East, Southeast Asia, and the Indian subcontinent (i.e., the countries of Cambodia, China, India, Japan, Korea, Malaysia, Pakistan, Philippines, Thailand, and Vietnam). Individuals of Pacific Islander descent, according to the U.S. Census Bureau (2013), have origins in Hawaii, Guam, Samoa, and other Pacific Islands. These are the definitions for Asian and Pacific Islander descent used in this paper.

Asian/Pacific Islander women living in the United States - whether newcomers, immigrants, permanent residents, or citizens-face specific mental health challenges. For example, in a national survey, AAPIW had the highest rate compared to White, Black, and Hispanic women of reporting trauma from being a refugee or civilian in a war zone (Roberts, Gilman, Breslau, Breslau, \& Koenen, 2011). AAPIW hold more negative cognitions (i.e., views about the self, the world, and self-blame) than their White counterparts about sexual abuse events that occurred in the past, which increases their likelihood of developing

\footnotetext{
${ }^{a}$ University of Nevada, Las Vegas, USA

${ }^{b}$ University of Pittsburgh, USA

Corresponding Author:

Andrew Thomas Reyes, PhD, MSN, RN

Assistant Professor

University of Nevada, Las Vegas, School of Nursing

Email: andrewthomas.reyes@unlv.edu
} 
post-traumatic stress disorder (Koo, Nguyen, Gilmore, Blayney, \& Kaysen, 2014). Furthermore, among women ages 25 to 44, AAPIW had the highest increase in suicide rate from 2009 to 2014 (91\%) compared to their Black $(20 \%)$ and Hispanic $(30 \%)$ counterparts (Curtin, Warner, \& Hedegaard, 2016). Suicide is the second leading cause of death among AAPIW aged 20 to 24 years (Centers for Disease Control and Prevention, 2013). In a study of acculturated AAPIW, over $40 \%$ of participants reported currently experiencing moderate to severe depression while $57 \%$ of these AAPIW did not have depression (Augsberger, Yeung, Dougher, \& Hahm, 2015). Studies have shown that stress related to assimilating into American culture, experiences of racial and gender discrimination, and history of sexual abuse exacerbated the mental and psychological distress of AAPIW (Hong, Walton, Tamaki, \& Sabin, 2014; Hahm, Kolaczyk, Lee, Jang, \& Ng, 2012; Sandil, Robinson, Brewster, Wong, \& Geiger, 2015). Yet many AAPIW with mental illnesses choose not to access mental health care services primarily due to the stigma surrounding mental illness and decreased perceived need for specialty services (Appel, Huang, Ai, \& Lin, 2011; Augsberger et al., 2015; Kimerling \& Baumrind, 2005).

Nevertheless, it is evident that some AAPIW faced with overwhelming challenges do not succumb to the debilitating effects of mental illness and other stress-induced psychological disabilities. Instead, they somehow thrive, and their ability to do so could be attributed to the phenomenon of psychological resilience. Additionally, the nature of resilience as being flexible, modifiable, and learnable implies that resilience can be taught and developed (Benard, 2004; Seligman, Ernst, Gillham, Reivich, \& Linkins, 2009). Hence, studying the resilience of AAPIW can shed light on effective ways of fostering resilience and positive adaptation in individuals going forward.

The purpose of this integrative review was to analyze empirical reports on resilience of AAPIW. The findings may help direct further research and lead to practical applications for nursing practice. The research question at the heart of this review is: what is the current state of knowledge regarding the resilience of AAPIW?

\section{Method}

This review used Whittemore and Knafl's (2005) integrative review method to analyze and synthesize the literature on AAPIW's resilience. Unlike systematic review methods used to analyze random-controlled trials, Whittemore and Knafl's method allows for the search of both research and theoretical reports, which is particularly relevant to the purpose of this current integrative review, to determine the current state of knowledge regarding
AAPIW's resilience. This method has five stages, all of which have been implemented in this integrative review: (a) problem identification, (b) literature search, (c) data evaluation, (d) data analysis, and (e) presentation.

\section{Literature Search}

The literature search and screening of articles were conducted by the authors of this paper through searches of the following databases: Academic Search Premier, CINAHL, ERIC, Ethnic NewsWatch, GenderWatch, ProQuest Dissertations and Theses Global, ProQuest Sociological Abstracts, PsycINFO, PubMed, SAGE (Psychology and Sociology collections), Scopus, and Web of Science. The key words entered in the search included the following combinations of terms: (a) resilience, Asian American women; (b) resiliency, Asian American women; (c) hardiness, Asian American women; (d) resilience, Pacific Islander; (e) resiliency, Pacific Islander; (f) hardiness, Pacific Islander; (g) resilien*, Asian American; and (h) resilien*, Pacific Islander. In order to obtain all possible literature, the literature search did not stipulate a publication time period.

To be included in this review, papers had to be (a) written in English and (b) research or theoretical reports on resilience of AAPIW as defined by the U.S. Census Bureau (2013). Additionally, studies that have research participants from different racial groups and those including both men and women were included in the review as long as the studies yielded findings specifically related to resilience of AAPIW. The exclusion criteria of the search were (a) editorials and commentaries, (b) non-peer reviewed magazine articles, (c) study protocols, (d) conference abstracts, (e) books and book chapters and reviews, (f) studies of adolescents and children, and $(\mathrm{g})$ research that did not include resilience as part of the findings. This final exclusion criterion refers to research studies that discussed resilience as an implication rather than part of the study findings. Studies about adolescents and children were also excluded because developmental aspects of their resilience may be conceptually different than those of adult women. A manual search of articles through references of identified relevant articles was conducted; however, no articles that met the inclusion criteria were found.

The process of the literature search is represented in Figure 1. A total of 1,937 records were retrieved in the initial database search. Duplicates were removed, and, thereafter, three levels of article screenings were conducted (Figure 1). Altogether, 21 research papers related to resilience of AAPIW met the criteria and were included in the data analysis of the integrative review. Detailed characteristics of the literature sample are included in Table 1. This final set of articles was also evaluated for methodological rigor 
and relevance of the findings to the research question. Regardless of the results of methodological evaluation of the articles, all articles were retained in the data analysis stage, as suggested by Whittemore and Knafl (2005).

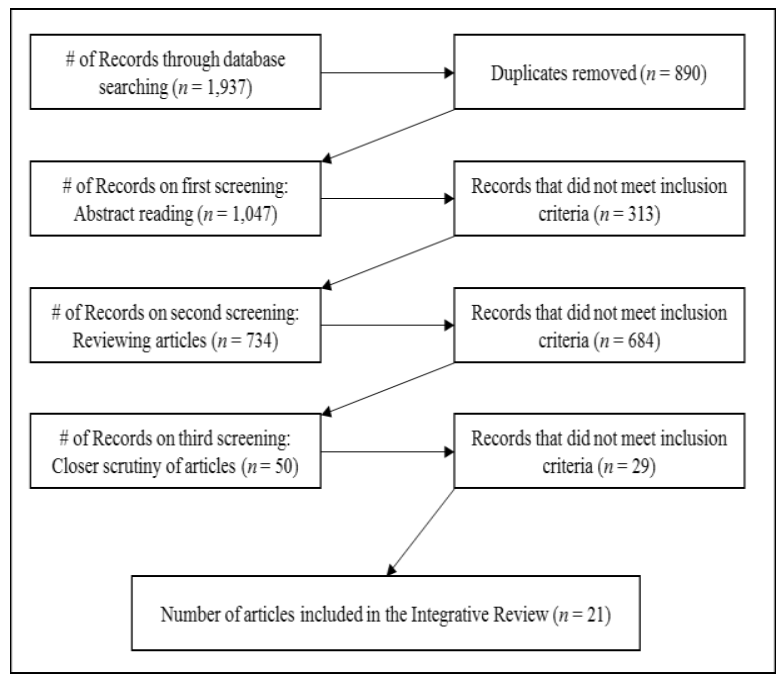

Figure 1. Flowchart of the process of identifying and selecting articles.

\section{Results}

Thirteen qualitative (Table 1) and eight quantitative (Table 2) records were included in the review. All of the 21 articles were research studies. No theoretical papers that met the inclusion criteria were found in the search. There were nine qualitative research studies (Cheng, 2013; Chu \& Leasure, 2010; Lee, 2013; Maruoka, 2008; Singh, Hays, Chung, \& Watson, 2010; Soans, 2012; Sung, Szymanski, \& Henrichs-Beck-2015; Yang, 2014; Yang \& Shin, 2008) and two quantitative research studies (Lee, Brown, Mitchell, \& Schiraldi, 2008; Lim \& Ashing-Giwa, 2013) that particularly focused on AAPIW. The remaining ten research studies involved women from mixed racial groups (Clauss-Ehlers, Yang, \& Chen, 2006; Lawson \& Satti, 2016; Wakeel, 2009), both Asian men and women (Dial, 2007; Fujisaki, 2014; Hamid, 2007; Kallampally, 2005; Kodama, 2015; Ta, 2015), and both men and women from mixed racial groups (Kwong, Du, \& Xu, 2015). These remaining ten studies were retained in the review because they included findings specific to the resilience of AAPIW. Sample sizes of studies varied from 6 to 2,223. A total of 2,452 AAPIW subjects out of 4,327 research participants for all of the studies were included in the review. The studies included the following specific Asian ethnic categories: Chinese, Filipino,
Hmong, Japanese, Korean, Laotian, South Asian (i.e., Indian and Pakistani), Taiwanese, and Vietnamese. Only one study (Wakeel, 2009) included Pacific Islander subjects but these subjects were subsumed in the larger Asian/Pacific Islander category. The operational definition of AAPIW as used in the screening of the articles was also similar to the definitions used in the studies reviewed.

Findings were analyzed using Whittemore and Knafl's (2005) four steps of data analysis (data reduction, data display, data comparison, and conclusion drawing/verification) in order to arrive at common themes and patterns. Five main themes emerged from the data analysis: (a) resilience as conceptualized as a coping strategy, (b) resilience as related to social support and network, (c) resilience as an enduring phenomenon, (d) resilience as connected to bicultural identity, and (e) resilience as an emancipatory perspective and experience.

\section{Resilience as Conceptualized as a Coping Strategy}

Most of the studies included in the review described resilience as a coping strategy used by AAPIW to persevere through difficult experiences and to resolve challenging situations. For example, older Vietnamese women immigrants in Chu and Leasure's (2010) study demonstrated resilience through their ability to endure hardships in their journey from wartorn Vietnam to an uncertain new life in America. Korean immigrant women who experienced abuse from their American husbands described resilience as "surviving and adjusting to their American lives" (Yang \& Shin, 2008, p. 49). Low-income Chinese immigrant women exhibited resilience through actions such as persisting through menial jobs and battling the loneliness and fear of living in communities where racially motivated aggressions were prevalent (Cheng, 2013).

As a coping strategy, resilience not only relates to dealing with challenges but also to achieving goals. For example, the 1.5-generation (those who immigrated to the United States when they were children) Hmong American women in Yang's (2014) study demonstrated resilience in dealing with the challenges of their career development by adopting positive perspectives instead of negative ones, focusing on achieving goals, and constantly reflecting on their actions to assess what they could improve on going forward. In Ta's (2015) study, Vietnamese American students characterized resilience as a strategy for navigating through different sources of support to achieve their educational goals. South Asian adult women who were victims of sexual abuse viewed resilience as a coping strategy for healing and self-care (Singh et al., 2010). 
Table 1. Summary of Qualitative Studies on Resilience of AAPIW

\begin{tabular}{|c|c|c|c|c|}
\hline $\begin{array}{l}\text { Authors } \\
\text { (Year) }\end{array}$ & Purpose of the Study & Participants & Design & Relevant Findings \\
\hline $\begin{array}{l}\text { Cheng } \\
(2013)\end{array}$ & $\begin{array}{l}\text { Describe the mean- } \\
\text { ings of living in a } \\
\text { U.S. Chinatown }\end{array}$ & $\begin{array}{l}8 \text { working-class Chinese im- } \\
\text { migrant women }\end{array}$ & Phenomenology & $\begin{array}{l}\text { Resilience: a "wobbly bed" that } \\
\text { stands despite immobilities, } \\
\text { structural injustice, and racial } \\
\text { antagonisms }\end{array}$ \\
\hline $\begin{array}{l}\text { Chu \& } \\
\text { Leasure } \\
(2010)\end{array}$ & $\begin{array}{l}\text { Explore meaning of } \\
\text { quality of life }\end{array}$ & $\begin{array}{l}33 \text { Vietnamese women aged } \\
56-85 \text { years }\end{array}$ & Ethnography & $\begin{array}{l}\text { Two main themes: resiliency and } \\
\text { security as context of adaptation }\end{array}$ \\
\hline $\begin{array}{l}\text { Fujisaki } \\
(2014)\end{array}$ & $\begin{array}{l}\text { Explore experience } \\
\text { of race and racism }\end{array}$ & $\begin{array}{l}6 \text { Asian Americans, aged } 40- \\
65 \text { years ( } 5 \text { were women) }\end{array}$ & $\begin{array}{l}\text { Case study, bio- } \\
\text { graphical } \\
\text { method }\end{array}$ & $\begin{array}{l}\text { Experiences of racial micro- } \\
\text { aggressions were related to both } \\
\text { psychological distress and resilience }\end{array}$ \\
\hline $\begin{array}{l}\text { Kwong } \\
\text { et al. } \\
(2015)\end{array}$ & $\begin{array}{l}\text { Examine relation- } \\
\text { ship between race, } \\
\text { connectedness, and } \\
\text { resources }\end{array}$ & $\begin{array}{l}17 \text { African and Asian Amer- } \\
\text { icans ( } 6 \text { were Asian women) }\end{array}$ & $\begin{array}{l}\text { Constant com- } \\
\text { parison method }\end{array}$ & $\begin{array}{l}\text { Family and friend connections and } \\
\text { community resources as components } \\
\text { of resilience }\end{array}$ \\
\hline $\begin{array}{l}\text { Lawson } \\
\& \text { Satti } \\
(2016)\end{array}$ & $\begin{array}{l}\text { Examine post- } \\
\text { divorce coping } \\
\text { strategies of women }\end{array}$ & $\begin{array}{l}12 \text { White, Black, and Paki- } \\
\text { stani divorced mothers ( } 2 \\
\text { were Pakistani) }\end{array}$ & $\begin{array}{l}\text { Grounded } \\
\text { theory }\end{array}$ & $\begin{array}{l}\text { Three themes of coping strategies of } \\
\text { Pakistani women (keeping busy, } \\
\text { family support, and religious } \\
\text { support) }\end{array}$ \\
\hline $\begin{array}{l}\text { Lee } \\
(2013)\end{array}$ & $\begin{array}{l}\text { Explore unique } \\
\text { aspects and } \\
\text { contextual } \\
\text { influences of career } \\
\text { development }\end{array}$ & $\begin{array}{l}12 \text { Asian American female } \\
\text { visual artists }\end{array}$ & $\begin{array}{l}\text { Qualitative, } \\
\text { consensual } \\
\text { qualitative } \\
\text { research }\end{array}$ & $\begin{array}{l}\text { Eight domains emerged from the } \\
\text { analysis, and resilience is subsumed } \\
\text { under the domain of strengths } \\
\text { contributing to career development }\end{array}$ \\
\hline $\begin{array}{l}\text { Marouka } \\
(2008)\end{array}$ & $\begin{array}{l}\text { Examine identity } \\
\text { construction related } \\
\text { to the tradition of } \\
\text { veiling }\end{array}$ & $\begin{array}{l}40 \text { second-generation South } \\
\text { Asian Muslim women }\end{array}$ & Ethnography & $\begin{array}{l}\text { Experience of cultural "difference" } \\
\text { and "disadvantage" as a source of } \\
\text { resilience and political activism }\end{array}$ \\
\hline $\begin{array}{l}\text { Singh et al. } \\
(2010)\end{array}$ & $\begin{array}{l}\text { Describe lived } \\
\text { experience of } \\
\text { resilience and child } \\
\text { sexual abuse }\end{array}$ & $\begin{array}{l}13 \text { South Asian adult women } \\
\text { who were survivors of child } \\
\text { sexual abuse }\end{array}$ & Phenomenology & $\begin{array}{l}\text { Two overarching themes: the South } \\
\text { Asian context and resilience } \\
\text { strategies }\end{array}$ \\
\hline $\begin{array}{l}\text { Soans } \\
(2012)\end{array}$ & $\begin{array}{l}\text { Explore motherhood } \\
\text { across generations }\end{array}$ & $\begin{array}{l}8 \text { South Asian women ( } 4 \\
\text { dyads of mother-daughter) }\end{array}$ & $\begin{array}{l}\text { Interpretative } \\
\text { phenomenology }\end{array}$ & $\begin{array}{l}\text { Narratives of intergenerational } \\
\text { traumatic experiences and resilience } \\
\text { enduring through generations }\end{array}$ \\
\hline $\begin{array}{l}\text { Sung et al. } \\
(2015)\end{array}$ & $\begin{array}{l}\text { Understand the ex- } \\
\text { perience of lesbian } \\
\text { and bisexual women }\end{array}$ & $\begin{array}{l}50 \text { Asian American sexual } \\
\text { minority women }\end{array}$ & $\begin{array}{l}\text { Content } \\
\text { analysis }\end{array}$ & $\begin{array}{l}\text { Resilience was an empowerment } \\
\text { strategy to cope with oppression }\end{array}$ \\
\hline Тa (2015) & $\begin{array}{l}\text { Examine experi- } \\
\text { ences of first-gener- } \\
\text { ation Vietnamese } \\
\text { American students }\end{array}$ & $\begin{array}{l}7 \text { first-generation Vietnam- } \\
\text { ese American college stu- } \\
\text { dents ( } 4 \text { were women) }\end{array}$ & $\begin{array}{l}\text { Narrative } \\
\text { inquiry }\end{array}$ & $\begin{array}{l}\text { Resilience in navigating through } \\
\text { support networks; engagement in } \\
\text { extracurricular activities; language } \\
\text { and culture on identity formation }\end{array}$ \\
\hline $\begin{array}{l}\text { Yang } \\
(2014)\end{array}$ & $\begin{array}{l}\text { Describe meaning of } \\
\text { career development }\end{array}$ & $\begin{array}{l}20 \text { 1.5-generation Hmong } \\
\text { American women }\end{array}$ & $\begin{array}{l}\text { Modified con- } \\
\text { sensual qualita- } \\
\text { tive research }\end{array}$ & $\begin{array}{l}\text { Resilience, a personal characteristic } \\
\text { to overcome challenges and a } \\
\text { domain of career development }\end{array}$ \\
\hline $\begin{array}{l}\text { Yang \& } \\
\text { Shin (2008) }\end{array}$ & $\begin{array}{l}\text { Describe the } \\
\text { resilience and } \\
\text { psycho- social well- } \\
\text { being after marital } \\
\text { crises }\end{array}$ & $\begin{array}{l}11 \text { Korean women who were } \\
\text { divorced/separated from } \\
\text { their American soldier hus- } \\
\text { bands }\end{array}$ & Ethnography & $\begin{array}{l}\text { Four determinants of psychological } \\
\text { well-being of participants: marital } \\
\text { and family relations, community } \\
\text { participation, finances, and health }\end{array}$ \\
\hline
\end{tabular}


Table 2. Summary of Quantitative Studies on Resilience of AAPIW

\begin{tabular}{|c|c|c|c|c|}
\hline $\begin{array}{l}\text { Authors } \\
\text { (Year) }\end{array}$ & Purpose of the Study & Participants & $\begin{array}{l}\text { Design, (Resilience } \\
\text { Tool) }\end{array}$ & Relevant Findings \\
\hline $\begin{array}{l}\text { Clauss- } \\
\text { Ehlers et al. } \\
(2006)\end{array}$ & $\begin{array}{l}\text { Examine the relationship } \\
\text { between ethnic and } \\
\text { gender identities with } \\
\text { cultural resilience }\end{array}$ & $\begin{array}{l}200 \text { female } \\
\text { undergraduate and } \\
\text { graduate students of a } \\
\text { Northeastern State } \\
\text { University ( } 50 \text { were } \\
\text { Asians) }\end{array}$ & $\begin{array}{l}\text { Correlational } \\
\text { (researcher- } \\
\text { developed } \\
\text { Cultural } \\
\text { Resilience } \\
\text { Survey) }\end{array}$ & $\begin{array}{l}\text { Latina and African American } \\
\text { students were significantly more } \\
\text { resilient than Asian and White } \\
\text { Americans }(p<.002) \text {. Gender and } \\
\text { ethnic identity significantly } \\
\text { related to resilience for the entire } \\
\text { sample }\end{array}$ \\
\hline $\begin{array}{l}\text { Dial } \\
(2007)\end{array}$ & $\begin{array}{l}\text { Examine participants' } \\
\text { health status, health care } \\
\text { access, and satisfaction } \\
\text { of health care services }\end{array}$ & $\begin{array}{l}192 \text { Filipino Americans, } \\
\text { aged } 55 \text { years and older } \\
\text { (107 were women) }\end{array}$ & $\begin{array}{l}\text { Correlational } \\
\text { (Resilience Scale } \\
\text { by Wagnild \& } \\
\text { Young, 1993) }\end{array}$ & $\begin{array}{l}\text { Filipino women had higher } \\
\text { resilience scores than men, but } \\
\text { men had higher physical health } \\
\text { scores than women }(p=.02)\end{array}$ \\
\hline $\begin{array}{l}\text { Hamid } \\
(2007)\end{array}$ & $\begin{array}{l}\text { Determine relationship } \\
\text { between perceived } \\
\text { parental acculturation } \\
\text { and psychological well- } \\
\text { being }\end{array}$ & $\begin{array}{l}61 \text { second-generation } \\
\text { South Asian college } \\
\text { students, aged } 18-27 \\
\text { years ( } 48 \text { were women) }\end{array}$ & $\begin{array}{l}\text { Correlational } \\
\text { (F-COPES by } \\
\text { McCubbin, Olson, } \\
\& \text { Larsen, 1981) }\end{array}$ & $\begin{array}{l}\text { Women scored higher than men } \\
\text { on acquiring social support }(p< \\
.05) \text { and mobilizing family to } \\
\text { acquire and accept help }(p<.01)\end{array}$ \\
\hline $\begin{array}{l}\text { Kallam- } \\
\text { pally } \\
(2005)\end{array}$ & $\begin{array}{l}\text { Determine effects of } \\
\text { gender, resilience, } \\
\text { acculturation, and } \\
\text { spirituality on marital } \\
\text { satisfaction }\end{array}$ & $\begin{array}{l}109 \text { Asian Indian } \\
\text { immigrants, living in } \\
\text { the USA }(47.7 \% \text { were } \\
\text { women })\end{array}$ & $\begin{array}{l}\text { Correlational } \\
\text { (Ego Resilience } \\
\text { Scale } 89 \text { by Block } \\
\text { \& Kremen, 1996) }\end{array}$ & $\begin{array}{l}\text { No significant difference between } \\
\text { women and men on resilience. No } \\
\text { statistically significant } \\
\text { relationship between resilience } \\
\text { and marital satisfaction }\end{array}$ \\
\hline $\begin{array}{l}\text { Kodama } \\
(2014)\end{array}$ & $\begin{array}{l}\text { Examine the relationship } \\
\text { between collective racial } \\
\text { self-esteem, resiliency, } \\
\text { and leadership self- } \\
\text { efficacy }\end{array}$ & $\begin{array}{l}\text { 2,223 Asian American } \\
\text { college and university } \\
\text { students ( } 59 \% \text { were } \\
\text { women) }\end{array}$ & $\begin{array}{l}\text { Secondary data } \\
\text { analysis, SEM } \\
\text { (CD-RISC } 10 \\
\text { items by } \\
\text { Campbell-Sills \& } \\
\text { Stein, 2007) }\end{array}$ & $\begin{array}{l}\text { No significant difference between } \\
\text { genders on the relationship } \\
\text { between resilience and leadership } \\
\text { self-efficacy (LSE). The path } \\
\text { between resilience and LSE was } \\
\text { significant for both men and } \\
\text { women }(p<.05)\end{array}$ \\
\hline $\begin{array}{l}\text { Lee et al. } \\
(2008)\end{array}$ & $\begin{array}{l}\text { Determine association } \\
\text { between resilience and } \\
\text { self-esteem, optimism, } \\
\text { religiousness, and } \\
\text { cultural interdependency }\end{array}$ & $\begin{array}{l}200 \text { Korean-American } \\
\text { elderly mothers and } 170 \\
\text { of their adult daughters }\end{array}$ & $\begin{array}{l}\text { Correlational } \\
\text { (Resilience Scale } \\
\text { by Wagnild \& } \\
\text { Young, 1993) }\end{array}$ & $\begin{array}{l}\text { Mothers and daughters } \\
\text { demonstrated below than normal } \\
\text { resilience scores. Self-esteem was } \\
\text { the most significant predictor of } \\
\text { resilience for both mothers and } \\
\text { daughters }(p<.01)\end{array}$ \\
\hline $\begin{array}{l}\text { Lim \& } \\
\text { Ashing- } \\
\text { Giwa } \\
(2013)\end{array}$ & $\begin{array}{l}\text { Test the Resilience } \\
\text { Model of family } \\
\text { adjustment and } \\
\text { adaptation (flexibility, } \\
\text { social support, } \\
\text { communication, health- } \\
\text { related quality of life) }\end{array}$ & $\begin{array}{l}157 \text { Chinese and Ko- } \\
\text { rean American breast } \\
\text { cancer survivors }\end{array}$ & $\begin{array}{l}\text { Correlational, } \\
\text { SEM } \\
\text { (no specific resili- } \\
\text { ence tool used*) }\end{array}$ & $\begin{array}{l}\text { Hypothesized model demon- } \\
\text { strated an excellent fit for both } \\
\text { Chinese and Korean breast cancer } \\
\text { survivors: } \\
X^{2}(72)=75.80, p=.36, \text { CFI }= \\
0.99, \text { RMSEA }=.02\end{array}$ \\
\hline $\begin{array}{l}\text { Wakeel } \\
\text { (2009) }\end{array}$ & $\begin{array}{l}\text { Determine the } \\
\text { relationship between } \\
\text { maternal resiliency and } \\
\text { race/ethnicity }\end{array}$ & $\begin{array}{l}948 \text { mothers who gave } \\
\text { birth within the past } 120 \\
\text { days }(14.9 \% \text { were } \\
\text { Asians/Pacific } \\
\text { Islanders) }\end{array}$ & $\begin{array}{l}\text { Quantitative, lo- } \\
\text { gistic regression } \\
\text { models } \\
\text { (researcher- } \\
\text { developed } \\
\text { Maternal } \\
\text { Resiliency) } \\
\end{array}$ & $\begin{array}{l}\text { Asian/Pacific Islander mothers } \\
\text { were } 2.2 \text { times as likely as Whites } \\
\text { to have a lower aspect of } \\
\text { resilience (neighborhood support/ } \\
\text { reciprocal exchange scale) }\end{array}$ \\
\hline
\end{tabular}

Note. F-COPES = Family Crisis Oriented Personal Evaluation Scales; LES = Leadership self-efficacy, SEM = Structural Equation Modeling; and *no specific resilience tool used in Lim \& Ashing-Giwa's (2013) study means that they conceptualized resilience as comprising of flexibility, social support, communication, and health-related quality of life. 
AAPIW used resilience as a form of empowerment in dealing with racial and gender discrimination. For example, Asian American lesbian and bisexual women described resilience as actions taken in dealing with oppression stemming from intolerance of their sexual orientation (Sung et al., 2015). South Asian Muslim American women applied resilience in coping with different forms of discrimination related to their veiling tradition (Mauroka, 2008). Middleaged Asian Americans characterized resilience as a defense strategy against incidents of racial micro-aggressions (Fujisaki, 2014).

Additionally, AAPIW used resilience as a coping strategy for dealing with challenges in the family. Narratives of South Asian older mothers and adult daughters depicted resilience as coping with difficulties of family life, like a death in the family (Soans, 2012). Pakistani women who divorced their husbands described resilience as managing their mental distress, obtaining family support, and relying on spiritual beliefs (Lawson \& Satti, 2016). Asian American female visual artists portrayed resilience as a way of positively coping with their families' disapproval of their career choice (Lee, 2013). The quantitative studies in this integrative review conceptualized resilience as a coping strategy for acquiring and mobilizing social support (Hamid, 2007), dealing with fluctuations in daily life (Kallampally, 2005), and handling challenging situations (Clauss-Ehlers et al., 2006; Dial, 2007; Kodama, 2015; Lee et al., 2008).

In relation to coping with depression and psychological distress, only Kallampally's (2005) study showed a negative relationship between depression and psychological resilience among Asian Indian Americans. Other studies that measured depression (Dial 2007; Hamid, 2007) did not investigate the direct relationship between resilience and depression or psychological distress.

\section{Resilience as Related to Social Support and Network}

Another theme prominent within the findings of these studies is the relationship between resilience and social support such as the notion that resilience is enhanced by perceived support of AAPIW's social network. Family was the most common source of social support (Dial, 2007; Hamid, 2007; Kallampally, 2005; Lee et al., 2008; Lim \& Ashing-Giwa, 2013; Wakeel, 2009). Other sources of social support evident in the studies were individuals from the church or temple, friends, and people of the same ethnic background (Chu \& Leasure, 2010; Clauss-Ehlers et al., 2006; Kodama, 2015; Kwong et al., 2015; Lawson \& Satti, 2016; Maruoka, 2008; Singh et al. 2010; Sung et al., 2015; Ta, 2015; Yang, 2014; Yang \& Shin,
2008). However, families, friends, and acquaintances from similar ethnic backgrounds were not always supportive. For example, selected narratives in Yang and Shin's (2008) study depict unsupportive views from the Korean church, a significant institution within the Korean community. Some Korean immigrant women in this study who were married to American soldiers perceived that they were being labeled in their churches as Yanggongju (Western sluts or prostitutes), and thus felt marginalized from community groups they had hoped would support them. In another example, while some families of Asian American lesbian and bisexual women were supportive of their sexual orientation, most were close-minded to their lifestyle (Sung et al., 2015).

Social support as an aspect of AAPIW's resilience provided a foundational collective identity that enabled AAPIW to participate in political activism and social advocacy. For example, support from the Asian American queer community empowered Asian American lesbian and bisexual women to break their silence, engage in social activism, and confront acts of discrimination (Sung et al., 2015). South Asian women learned to source strength from their South Asian community and become more vocal about childhood sexual abuse (Singh et al., 2010). Young South Asian Muslim American women drew support from one another and fought discrimination by transforming the stigmatized view of veiling or wearing the hijab (Maruoka, 2008). Finally, narratives of Pakistani women coming together to form a divorce mentoring group is another example of the connection between social support and resilience (Lawson \& Satti, 2016).

\section{Resilience as an Enduring Phenomenon}

The third theme that emerged from the analysis is resilience as an enduring phenomenon such as a process that withstands the passage of time and generations. For example, resilience helped older Vietnamese women immigrants survive the atrocities of the Vietnam War and overcome different kinds of adversities after moving to the United States (Chu \& Leasure, 2010). Chinese immigrant women shared stories of enduring the long wait of the immigration process before coming to the United States and how they continued to thrive despite living in poverty in a Chinatown community in California (Cheng, 2013). Additionally, South Asian adult daughters who were either born in the United States or spent their childhood there expressed how they adopted their mothers' resilience into their own lived experience (Soans, 2012). This is an example of resilience being transmitted through generations, hence, resilience as an enduring phenomenon. 
Resilience, as an enduring phenomenon, is also represented in AAPIW's perseverance in the midst of adversities. Qualitative studies best exemplify resilience as perseverance. For example, Korean immigrant women lived through years of being psychologically, physically, and sexually abused by their American husbands and yet found the strength to survive or even leave the abusive relationships (Yang \& Shin, 2008). South Asian young Muslim women demonstrated resilience by enduring discrimination for wearing the hijab and even paradoxically used the stigmatized veil as a symbol of confronting sexism and racism (Maruoka, 2008). Other representations of resilience as perseverance include Hmong American women's ability to broaden their perspectives about the barriers impeding their career development by considering different viewpoints (Yang, 2014); first-generation Vietnamese female students' actions of persevering in the face of numerous obstacles to achieve their academic goals (Ta, 2015); and South Asian women (who were also victims of sexual abuse) describing their resilience as being unyielding, and speaking of having a sense of hope despite living with the burden of a traumatic past (Singh et al., 2010).

Quantitative studies also conceptualized resilience as an enduring phenomenon. For example, Dial (2007) and Lee et al. (2008) used Wagnild and Young's (1993) Resilience Scale, an instrument in which perseverance is a key aspect. Additionally, Kodama's (2015) quantitative study portrays resilience as the ability of Asian Americans to endure racial stereotypes.

\section{Resilience as Connected to Bicultural Identity}

The studies have shown that the way in which AAPIW integrate their culture of origin with American culture informs how they handle their challenges. Bicultural identity thus plays a significant role in the resilience of AAPIW. In Cheng's (2013) study of low-income Chinese immigrant women, participants described their resilience as adapting to rather than being negatively impacted by the American lifestyle. In Maruoka's (2008) study, South Asian Muslim American women perceived the conflicting aspects of Islamic and American belief systems and cultures, but imbibed aspects of both cultures and were able to use their resilience in constructing a positive second-generation identity for themselves. In Soans's (2012) study, adult daughters of South Asian mothers portrayed their resilience as based on both "blend(ing) in" (p. 269) with the American culture as well as honoring their parents' culture. Consequently, they took their mothers' traumatic yet resilient experiences and applied them to their own construction of being empowered South Asian American women. Findings from the quantitative studies revealed a relationship between resilience and bicultural identity. Social support, as an aspect of family resilience, was directly related to acculturation for both Chinese- and KoreanAmerican women (Lim \& Ashing-Giwa, 2013). In Wakeel's (2009) study, Asian American/Pacific Islander (AAPI) mothers (who were mostly foreignborn) reported lower levels of resilience than their White counterparts, and this result was due to the mediating influence of AAPI mothers' low levels of acculturation.

Resilience, as connected to bicultural identity, is also evident in narratives about AAPIW's ability to resolve internal emotional conflicts associated with their ethnic identity. For instance, despite being stigmatized as sexual objects, Korean women who were divorced or separated from their American husbands were able to obtain social support from fellow Koreans (Yang \& Shin, 2008). In another example, although recently divorced Pakistani women recognized the prohibition of remarriage within the Islamic culture, they were still able to support other Pakistani women experiencing similar distress (Lawson \& Satti, 2016). Finally, South Asian women knew the topic of child sexual abuse was taboo in their culture but were able to find solace in venting about their traumatic experience to others within their community (Singh et al., 2010).

Lastly, acculturation and generational status were examined in relation to resilience. For example, four studies (Kodama, 2015; Lee et al., 2008; Lim \& Ashing-Giwa, 2013; Wakeel, 2009) found a significant relationship between acculturation and resilience of AAPIW. More particularly, Wakeel (2009) reported that U.S.-born AAPI mothers had higher acculturation and resilience levels than their immigrant counterparts. More investigation is needed in this area because three studies (Dial, 2007; Hamid, 2007; Kallampally, 2005) examined resilience and acculturation levels, but did not determine the direct relationship between the two.

\section{Resilience as an Emancipatory Perspective and Experience}

The studies reviewed make it clear that AAPIW were not only dealing with personal challenges; they were also confronting broader social challenges such as discrimination and marginalization. AAPIW constantly faced oppression from structural barriers, which hindered their expression of resilience. These barriers came in different forms, such as systemic discrimination and social exclusion due to their ethnic and gender identities. AAPIW's daily actions of challenging and moving through these 
barriers demonstrated resilience as a journey of emancipation. The women in these studies recognized that resilience is not only a personal endeavor but also a collective effort to resist the structures that perpetuate racial and gender discrimination.

Only one quantitative study explicitly articulated resilience as an emancipatory perspective. Dial (2007) used Jones and Meleis's (1993) health empowerment model, which demonstrates an individual's ability to mobilize resources that in turn leads to empowerment in health. Qualitative studies included in the review provided more portrayals of resilience as an emancipatory experience. For example, in Fujisaki's (2014) study, AAPIW in middle adulthood represented their resilience as a way of externalizing racial micro-aggressions by attributing negative incidents to the aggressor's "stupidity or ignorance" (p. 192) rather than internalizing these troubling events (i.e., feeling inferior, invisible, and powerless). Resilience as a form of emancipation was liberating and empowering for AAPIW. As another example, some Korean women married to abusive American soldiers in Yang and Shin's (2008) study were able to leave the toxic relationship, while others remained with their husbands due to anxiety about leaving the relationship, living alone, and lacking the English language skills needed to survive on their own, among many other reasons. The emancipatory experience of AAPIW in abusive relationships is thus complex and subject to broader societal factors.

Chinese immigrant women living in poverty in the United States revealed stories of emancipation, albeit their experiences were often short-lived (Cheng, 2013). These women felt immobilized by economic and cultural constraints like working low-wage, menial jobs and dealing with racial aggressions on a daily basis. Despite facing discrimination, marginalization, and being disappointed by the "American Dream," they remained determined and hopeful to live the American life.

Resilience as an emancipatory experience also appeared in narratives of South Asian women, who talked about their child sexual abuse experiences within their ethnic community, despite the taboo against this subject, and afterwards reported a sense of moving to a "better place" and feeling liberated (Singh et al., 2010, p. 454). Using strategies of resilience, Pakistani women shifted from viewing themselves as "damaged" to "challenged by marital termination" (Lawson \& Satti, 2016, p. 428). Rather than feeling hopeless, they learned to believe in their agency to restore their lives to a state of well-being. Asian American lesbian and bisexual women demonstrated emancipation in resilience through resisting discrimination and engaging in social activism such as participating in leadership activities within the lesbian, gay, bisexual, transgender, and queer community (Sung et al., 2015). Finally, young South Asian Muslim American women transitioned from viewing the tradition of veiling as a practice that restricted autonomy to seeing it as an instrument for political activism (Maruoka, 2008). The veil was no longer a symbol of oppression, but rather one of empowerment and emancipation.

\section{Discussion}

The current state of knowledge regarding resilience of AAPIW mainly addresses the nature of AAPIW's resilience and the factors associated with it. Resilience of AAPIW is conceptualized as a coping strategy, depicted as being related to social support, described as an enduring phenomenon, shown to be associated with AAPIW's bicultural identity, and characterized as an emancipatory perspective and experience. Findings from the current integrative review suggest three implications for nursing practice and research.

First, the five themes that emerged from the review revealed that the resilience of AAPIW is a developmental process rather than a static or isolated event. AAPIW's resilience is developed through several episodes of stressful events, transmitted through generations, and enhanced by multiple and interrelated factors. These factors included acculturation levels, perceived social support, physical and mental health status, income, age, individual and collective ethnic identities, and experience of racial discrimination, among others. AAPIW's resilience is demonstrated in their lives prior to migrating to the United States, further developed during their experiences of adversities in their American lives, and transmitted to their offspring. These findings imply that resilience must be examined with a systems perspective (MacPhee, Lunkenheimer, \& Riggs, 2015), which means that resilience is not simply an outcome but a dynamic process developed through multiple pathways (Davis \& Cicchetti, 2004). Therefore, nurses who provide culturally sensitive health care services to AAPIW populations must not only integrate interventions that promote AAPIW's resilience but also consider the broader context in which this resilience is developed. In addition to supporting AAPIW's efforts to cope with personal challenges, health care practitioners should consider how other determinants of health (e.g., income, living conditions, and immigration status) impact AAPIW's well-being and resilience. Researchers may require longitudinal study designs to examine the development of resilience over time. Research studies should focus on AAPIW's resilience prior to coming to the United States and how their resilience evolved while living there. Finally, adult 
AAPIW's resilience is developmentally different from that of adolescents, so findings from studies involving mixed age groups should be disaggregated between adults and adolescents.

The second implication from the findings concerns the significant influence of culture on resilience of AAPIW. The studies in the review compared the resilience of AAPIW to that of individuals from other ethnic or racial groups and explored the relationship between resilience and ethnic identity, racial selfesteem, acculturation, and other culturally related constructs. Clauss-Ehlers et al. (2006) developed a cultural resilience instrument to further examine the nuances of culture affecting resilience. Resilience is thus a culturally oriented construct that must be examined with a cultural perspective. Nurses providing care to AAPIW must therefore consider and challenge their assumptions about the relationship between culture and resilience. For example, findings of studies in the review revealed that people of the same ethnicity were not necessarily supportive of one another; some AAPIW were not familiar with western health care practices; AAPIW with mental illnesses frequently did not seek treatment from mental health professionals; and AAPIW's immigration experience was not only a source of trauma but also a factor in enhancing resilience. Clinicians must continually examine their assumptions about how best to support the resilience of AAPIW, ensure their resilience programs are evidence-based, and apply culturally appropriate communication techniques to explore client preferences and expectations.

Findings suggest that researchers may need to disaggregate study findings by gender, use instruments that measure other nuances of acculturation (e.g., ethnic loyalty, food and music preferences, social connections with similar ethnic groups, and ethnic identity) to better understand the factors that influence resilience, and further explore the influence of immigration status and experience on the resilience of AAPIW. Furthermore, researchers should examine differences in resilience among specific Asian ethnic groups, as putting these different ethnicities under one umbrella can lead to overlooking or neglecting critical challenges that Asian Americans face (Museus \& Truong, 2009). Finally, Holland and Palaniappan (2012) recommend that researchers collecting disaggregated data for Asian subgroups recognize the heterogeneity of these subgroups when interpreting results.

The third implication is the recognition of AAPIW as a marginalized group. The findings reveal that, similar to African- and Hispanic-American women, AAPIW are also marginalized by virtue of their racial and ethnic identity. Discrimination against AAPIW is usually covert because of the model minority stereotype ascribed to Asian Americans
(Chou \& Feagin, 2008; Espiritu, 2008). While the studies make it clear that many AAPIW suffered negative consequences from racism and sexism, many demonstrated resilience despite discrimination. These mixed results reflect the reality of the lives of AAPIW. They also suggest that more fieldwork needs to be done in empowering AAPIW to challenge the social structures that perpetuate their experiences of discrimination and consequent marginalization. Nurses are in key positions to enable AAPIW to negotiate the processes that marginalize them and to help them to be continually cognizant of their resilience and the fact that health care is accessible to them. Women who are more aware of racism and sexism in their environment are more likely to report adverse events and seek help for themselves (ClaussEhlers et al., 2006). Researchers need to conduct more studies using theoretical frameworks such as feminist theory and critical social theory to examine how specific nuances of discrimination AAPIW experience can facilitate and hinder their resilience. The narratives and data from the studies depicting the glass and bamboo ceilings many AAPIW struggle with and their daily experiences of marginalization, call for further research on how the intersectionality of race, class, and gender influence their resilience. By conducting intersectionality research about AAPIW, researchers can use their methods as a research investigation and a social/political advocacy strategy for AAPIW (Chun, Lipsitz, \& Shin, 2013).

\section{Conclusion}

This integrative review examined the current state of knowledge regarding the resilience of AAPIW. Results of this review revealed that AAPIW's resilience is based on their daily experience of adversities and discrimination. Findings from the review show that many AAPIW overcame their challenges and managed to positively adapt to their situations and use their adversities as a platform for social advocacy. However, the limited generalizability of the findings of the studies due to small sample sizes, the aggregation of AAPIW data with males and people of other ethnicities, and the lack of longitudinal designs warrant more exploration of the resilience of AAPIW. While many of the studies in the review investigated the relationship between generational status and acculturation with resilience, some studies did not examine the direct relationships between these components, despite including these measures in the research. This implies that further investigation is needed in these areas. Another limitation of the review is that studies involving women with mixed racial backgrounds and those who may or may not identify as Asian were not particularly explored. 
Results of the integrative review imply that AAPIW's resilience is a dynamic process that can be further developed and enhanced. Therefore, it is imperative that nurses advocate for programs and interventions that are not only culturally sensitive to AAPIW but also consider the balance between resilience and vulnerability of AAPIW. This means that nurses must implement interventions that both support AAPIW's strengths and capacities to withstand their difficult situations, while also acknowledging the social structures and determinants of health that exacerbate AAPIW's experiences of being marginalized. A next step would be to produce research proposals using mixed methods design and applying culturally informed resilience measures with a specific ethnic group of women.

\section{References}

Appel, H. B., Huang, B., Ai, A. L., \& Lin, C. J. (2011). Physical, behavioral, and mental health issues in Asian American women: Results from the National Latino Asian American Study. Journal of Women's Health, 20, 1703-1711. doi:org/10.1089/ jwh.2010.2726

Augsberger, A., Yeung, A., Dougher, M., \& Hahm, H. C. (2015). Factors influencing the underutilization of mental health services among Asian American women with a history of depression and suicide. BMC Health Services Research, 15, 1-11. doi:10.1186/s12913-015-1191-7

Benard, B. (2004). Resilience: What we have learned. San Francisco, CA: West Ed.

Block, J. H., \& Kremen, A. M. (1996). IQ and ego-resiliency: Conceptual and empirical connections and separateness. Journal of Personality and Social Psychology, 70, 349-361. doi:10.1037/00223514.70.2.349

Campbell-Sills, L., \& Stein, M. B. (2007). Psychometric analysis and refinement of the Connor-Davidson resilience scale (CD-RISC): Validation of a 10item measure of resilience. Journal of Traumatic Stress, 20, 1019-1028. doi:10.1002/jts.20271

Centers for Disease Control and Prevention. (2013). Leading cause of death by age group, Asian or Pacific Islander Female, 2013. Retrieved from https://www.cdc.gov/women/lcod/2013/womenasian_2013.pdf

Cheng, H. (2013). "A wobbly bed still stands on three legs": On Chinese immigrant women's experiences with ethnic community. Women \& Language, 36, 7-25.

Chou, R. D., \& Feagin, J. R. (2008). The myth of the model minority: Asian Americans facing racism. Boulder, CO: Paradigm.

Chu, N., \& Leasure, A. R. (2010). Aging in America: Quality of life among older Vietnamese women immigrants. Journal of Cultural Diversity, 17, 105109.

Chun, J. J., Lipsitz, G., \& Shin, Y. (2013). Intersectionality as a social movement strategy: Asian immigrant women advocates. Signs, 38, 917-940. doi:10.1086/669575
Clauss-Ehlers, C. S., Yang, Y. T., \& Chen, W. J. (2006). Resilience from childhood stressors: The role of cultural resilience, ethnic identity, and gender identity. Journal of Infant, Child, and Adolescent Psychotherapy, 5, 124-138. doi:10.2513/ s15289168jicap0501_7

Curtin, S. C., Warner, M., \& Hedegaard, H. (2016). Suicide rates for females and males by race and ethnicity: United States, 1999 and 2014. Retrieved from http://www.cdc.gov/nchs/data/hestat/suicide/rates_1999_2014.pdf

Davis, P. T., \& Cicchetti, D. (2004). Toward an integration of family systems and developmental psychopathology approaches. Development and Psychopathology, 16, 477-481. doi:10.1017 /S0954579404004626

Dial, M. N. (2007). Factors affecting the health of aging Filipino Americans (Doctoral dissertation). Retrieved from ProQuest. (UMI Order AAI3292128)

Dyer, J. G., \& McGuinness, T. M. (1996). Resilience: Analysis of the concept. Archives of Psychiatric Nursing, 5, 276-282. doi:10.1016/S0883-9417 (96)80036-7

Espiritu, Y. L. (2008). Asian American women and men: Labor, laws, and love (2nd ed.). Lanham, MI: Rowman \& Littlefield.

Fujisaki, A. (2014). Capacities for resilience and defenses against the psychological effects of racial microagressions among Asian Americans (Doctoral dissertation). Retrieved from ProQuest. (UMI Order 3683029)

Hahm, H. C., Kolaczyk, E., Lee, Y., Jang, J., \& Ng, L. (2012). Do Asian-American women who were maltreated as children have a higher likelihood for HIV risk behaviors and adverse mental health outcomes? Women's Health Issues, 22, e35-e43. doi:10.1016/j.whi.2011.07.003

Hamid, R. M. (2007). Perceived parental acculturation and psychological well-being of South Asian college students and young adults (Doctoral dissertation). Retrieved from ProQuest. (UMI Order 3280168)

Holland, A. T., \& Palaniappan, L. P. (2012). Problems with the collection and interpretation of Asian-American health data: Omission, aggregation, and extrapolation. Annals of Epidemiology, 22, 397-405. doi: 10.1016/j.annepidem.2012.04.001

Hong, S., Walton, E., Tamaki, E., \& Sabin, J. A. (2014). Lifetime prevalence of mental disorders among Asian Americans: Nativity, gender, and sociodemographic correlates. Asian American Journal of Psychology, 5, 353-363. doi:10.1037/a0035680

Jones, P. S., \& Meleis, A. I. (1993). Health is empowerment. Advances in Nursing Science, 15, 1-14. doi:10.1097/00012272-199303000-00003

Kallampally, G. A. (2005). Gender, psychological resilience, acculturation and spirituality as predictors of Asian Indian American marital satisfaction (Doctoral dissertation). Retrieved from ProQuest. (UMI Order 3178539)

Kimerling, R., \& Baumrind, N. (2005). Access to specialty mental health services among women in California. Psychiatric Services, 56, 729-734. 
Kodama, C. M. (2015). A structural model of leadership self-efficacy for Asian American students: Examining influences of collective racial esteem and resilience (Doctoral dissertation). Retrieved from ProQuest. (UMI Order 3641136)

Koo, K. H., Nguyen, H. V., Gilmore, A. K., Blayney, J. A., \& Kaysen, D. L. (2014). Posttraumatic cognitions, somatization, and PTSD severity among Asian American and white college women with sexual trauma histories. Psychological Trauma: Theory, Research, Practice, and Policy, 6, 337-344. doi:10.1037/a0033830

Kwong, K., Du, Y., \& Xu, Q. (2015). Healthy aging of minority and immigrant populations: Resilience in late life. Traumatology, 21, 136-144. doi:10.1037/ trm0000034

Lawson, E. J., \& Satti, F. (2016). The aftermath of divorce: Postdivorce adjustment strategies of South Asian, black, and white women in the United States. Journal of Divorce \& Remarriage, 57, 411-431. doi:10.1080/10502556.2016.1196849

Lee, H., Brown, S. L., Mitchell, M. M., \& Schiraldi, G. R. (2008). Correlates of resilience in the face of adversity for Korean women immigrating to the US. Journal of Immigrant and Minority Health, 10, 415-422. doi:10.1007/s10903-007-9104-4

Lee, S. Y. (2013). The career development of Asian American female visual artists (Doctoral dissertation). Retrieved from ProQuest. (UMI Order 3595117)

Lim, J., \& Ashing-Giwa, K. T. (2013). Is family functioning and communication associated with health-related quality of life for Chinese- and Korean-American breast cancer survivors? Quality of Life Research: An International Journal of Quality of Life Aspects of Treatment, Care and Rehabilitation, 22, 13191329. doi:10.1007/s11136-012-0247-y

Luthar, S. S., Cicchetti, D., \& Becker, B. (2000). The construct of resilience: A critical evaluation and guidelines for future work. Child Development, 71, 543-562. doi:10.1111/1467-8624.00164

Maruoka, E. (2008). Veiled passion: Negotiation of gender, race and religiosity among young Muslim American women (Doctoral dissertation). Retrieved from ProQuest (UMI Order 3340120)

MacPhee, D., Lunkenheimer, E., \& Riggs, N. (2015). Resilience as regulation of developmental and family processes. Family Relations, 64, 153-175. doi:10.1111/fare. 12100

McCubbin, H. I., Olson, D., \& Larsen, A. (1981). Family crisis oriented personal scales (F-COPES). In H. I. McCubbin, A. I., Thompson, \& M. A. McCubbin (Eds.), Family assessment: Resiliency, coping \& adaptation: Inventories for research and practice (pp. 455-507). Madison, WI: University of Wisconsin System.

Museus, S. D., \& Truong, K. A. (2009). Disaggregating qualitative data from Asian American college students in campus racial climate research and assessment. New Directions for Institutional Research, 142, 17-26. doi:10.1002/ir.293

Roberts, A. L., Gilman, S. E., Breslau, J., Breslau, N., \& Koenen, K. C. (2011). Race/ethnic differences in exposure to traumatic events, development of post-traumatic stress disorder, and treatmentseeking for post-traumatic stress disorder in the United States. Psychological Medicine, 41, 71-83. doi:10.1017/S0033291710000401

Rutter, M. (1993). Resilience: Some conceptual considerations. The Journal of Adolescent Health, 14, 626631. doi:10.1016/1054-139X(93)90196-V

Sandil, R., Robinson, M., Brewster, M. E., Wong, S., \& Geiger, E. (2015). Negotiating multiplemarginalizations: Experiences of South Asian LGBQ individuals. Cultural Diversity \& Ethnic Minority Psychology, 21, 76-88. doi:10.1037/a0037070

Seligman, M. P., Ernst, R., Gillham, J., Reivich, K., \& Linkins, M. (2009). Positive education: Positive psychology and classroom interventions. Oxford Review of Education, 35, 293-311. doi:10.1080/ 03054980902934563

Singh, A. A., Hays, D. G., Chung, Y. B., \& Watson, L. (2010). South Asian immigrant women who have survived child sexual abuse: Resilience and healing. Violence Against Women, 16, 444-458. doi:10.1177/1077801210363976

Soans, Y. A. (2012). Narratives of mothering across place, time, and generation: Immigration and motherhood for two generations of South Asian women in the United States (Doctoral Dissertation). Retrieved from ProQuest. (UMI Order 3519695)

Sung, M. R., Szymanski, D. M., \& Henrichs-Beck, C. (2015). Challenges, coping, and benefits of being an Asian American lesbian or bisexual woman. Psychology of Sexual Orientation and Gender Diversity, 2, 52-64. doi:10.1037/sgd0000085

Ta, B. T. (2015). Persistence, determination, and hard work are crucial ingredients for life: A narrative inquiry into the lives of first-generation Vietnamese American students (Doctoral dissertation). Retrieved from ProQuest. (UMI Order 3703043)

U.S. Census Bureau. (2013). Race. Retrieved from http://www.census.gov/topics/population/race/about.html

Wakeel, F. M. (2009). The role of maternal resiliency in the multi-level pathways between race lethnicity and birth outcomes in Los Angeles County (Doctoral dissertation). Retrieved from ProQuest. (UMI Order 3394932)

Wagnild, G. M., \& Young, H. (1993). Development and psychometric evaluation of the Resilience Scale. Journal of Nursing Measurement, 1, 165-178.

Whittemore, R., \& Knafl, K. (2005). The integrative review: Updated methodology. Journal of Advanced Nursing, 52, 546-553. doi:10.1111/j.1365-2648.2005. 03621.x

Yang, A. (2014). Themes in the career development of 1.5generation Hmong American women. Journal of Career Development, 41, 402-425. doi:10.1177/ 0894845313507775

Yang, J., \& Shin, K. (2008). Vulnerability, resilience and well-being of intermarriage: An ethnographic approach to Korean women. Journal of International Women's Studies, 10, 46-63. Retrieved from http://vc.bridgew.edu/jiws/vol10/iss2/5 